\title{
Daily Work Load Distribution to Increase Time Quality of Inpatients' Medical Record Document Procurement in X Hospital
}

\author{
Harjanti * Navis Yuliansyah, Kurnia Widyaningrum \\ * Correspondent Author: harjantidarmawan@yahoo.co.id \\ * Nusantara Inpatient Clinic, Malang, Indonesia
}

\section{INDEXING}

Keywords:

Medical Record-

Document;

Inpatient;

Overworked.
Kata Kunci:

Dokumen Rekam Medis;

Rawat Inap;

Terlalu Banyak Bekerja.

\begin{abstract}
A B S T R A C T
Procurement of inpatient medical record document is one of some indicators of a hospital's minimum service standards (SPM). According to the hospital MSS, the ideal procurement of inpatient medical record document is about $\leq 15$ minutes, however the procurement on the report of quality committee at the first semester on 2017 in X Hospital reaches 22,89 minutes. The study is aimed at identifying, determining the root of the problems, and trying to devise solutions to the problems. The study employs a qualitative approach by employing document analysis, in-depth interview, and ethnographic observation. The problems are identified by using three steps which are focus group discussion (FGD) by the board of directors, the head of division, and the head of unit X Hospital. The second step is time motion study at the place of inpatient registration, and the last is Urgency, seriousness, and growth (USG) in medical record unit. The study results show that the overload of inpatient admission officers' work is known to be the root of the problem. Solution to the procurement which is not in accordance with the hospital minimum service standard is to distribute the daily workload of inpatient admission officers to related units.
\end{abstract}

Pengadaan dokumen rekam medis rawat inap adalah salah satu dari beberapa indikator standar pelayanan minimum rumah sakit (SPM). Menurut rumah sakit MSS, pengadaan dokumen rekam medis rawat inap yang ideal adalah sekitar $\leq 15$ menit, namun pengadaan laporan komite mutu pada semester pertama tahun 2017 di Rumah Sakit X mencapai 22,89 menit. Penelitian ini bertujuan untuk mengidentifikasi, menentukan akar masalah, dan mencoba mencari solusi untuk masalah. Penelitian ini menggunakan pendekatan kualitatif dengan menggunakan analisis dokumen, wawancara mendalam, dan pengamatan etnografi. Masalah diidentifikasi dengan menggunakan tiga langkah yaitu focus group discussion (FGD) oleh dewan direksi, kepala divisi, dan kepala unit X Hospital. Langkah kedua adalah time motion study di tempat pendaftaran rawat inap, dan yang terakhir adalah Urgensi, keseriusan, dan pertumbuhan (USG) di unit rekam medis. Hasil penelitian menunjukkan bahwa kelebihan pekerjaan petugas penerimaan rawat inap diketahui sebagai akar masalah. Solusi untuk pengadaan yang tidak sesuai dengan standar pelayanan minimum rumah sakit adalah mendistribusikan beban kerja harian petugas penerimaan rawat inap ke unit terkait.

C) 2018 JMMR. All rights reserved

Article history: Received 2018-Apr-10 ; Revised 2018-Apr-11; Accepted 2018-May-04

\section{INTRODUCTION}

The procurement of inpatients' medical record document is an inseparable component of a hospital's health care service. The implementation of health care service could be measured by solving medical or nonmedical problems. ${ }^{1}$ Supplying a medical record document is one of nonmedical health services. Quality improvement is an utmost priority in every hospital. According to RI Law number 44, it states that hospitals ought to increase a high-quality and affordable service for the people so that the health welfare in Indonesia can be achieved as high as possible. A high-quality health service must be able to provide clear information regarding what, who, when, where, and how the health service will be and/or is carried out. ${ }^{2}$ The implementation of medical record of a health care institution is one of many important indicators regarding a hospital's service quality. The rate of inpatients' medical record document procurement is one of the things that indicates a good hospital service quality. ${ }^{3}$ According to Sabarguna in Firzah (2015), a rapid and accurate service is the wish of everyone, be it the service provider or the service recipient. ${ }^{4} \mathrm{~A}$ lengthy procurement of medical record documents will hinder patient transfer to the inpatient room.

One of the quality indicators is the fulfillment of Minimun Service Standard (SPM) of a hospital. SPM established several quality indicators, among which is the 
inpatients' medical record document procurement time. Inpatients' medical record document procurement time is the time a patient is admitted to be hospitalized by the doctor until the inpatient medical record is available in the patient ward. The inpatient medical record document procurement time that is not in accordance with the standard becomes one of the emerging issues in X Hospital. Hospital SPM states that the standard time to procure inpatient's medical record document is $\leq 15$ minute. The time needed by X Hospital is still 22,89 minutes. This substandard record is present at the first semester quality committee report of X Hospital in 2017. Based on all that, it is necessary to know the cause of the substandard inpatient's medical record document procurement time so that the formulation of the solution can be done. The study is aimed at identifying, determining the root of the problems, and trying to devise solutions to the problems.

\section{METHOD RESEARCH}

This study employs a qualitative approach. This study is performed at X Hospital for a period of two months which is September to October 2017 employing document analysis, in-depth interview, and ethnographic observation. The methods employed aimed to determine the root of the problem regarding substandard time needed to procure inpatient's medical record documents comprises of three steps. Firstly, is to perform focus group discussion by the board of directors, the head of division, and the head of unit X Hospital on 6 September 2017; The second step is a time motion study at the place of inpatient registration on Thursday, 28 September 2017; and the last is to perform urgency, seriousness, and growth (USG) in medical record unit from 2-4 October 2017. Solution alternative priority is selected via McNamara and Barber Johnson Graph Analysis.

\section{RESULT AND DISCUSSION}

The determination of the root of the problem during the time of substandard inpatient's medical record document procurement comprises of three steps. Firstly, is to perform focus group discussion by the board of directors, the head of division, and the head of unit X Hospital; The second step is a time motion study at the place of inpatient registration (TPPRI); and the last is to perform urgency, seriousness, and growth (USG) in medical record unit.

\section{Time Motion Study}

Time motion study is a work load measuring technique. Time and motion study is a systematic study method of a work system that aims to improve the system and method, to standardize the system and guideline, determine time standard and train workforce. ${ }^{5}$

Time motion study is performed directly at TPPRI. The measurement is done via a direct observation on all task performed by officers at TPPRI and timekeeping of the time needed by an officer in completing his duty.

Patient admission location in X Hospital is divided into three parts, namely TPPRI, outpatient TPP (TPPRJ) general patient and TPPRJ for JKN-KIS participant. In the patient admittance spot there are two label printing machines, one at the TPPRI and the other one is at the TPPRJ for JKN-KIS participant. Two identity bracelet printing machines are located in TPPRI, one is for blue bracelet and the other one is for the red bracelet.

The patients/their family register inpatient at TPPRI by bringing request of inpatient letter from outpatient unit doctor/emergency unit (UGD) of X Hospital. The registration officer informs regarding facilities and daily nursing room tariff as well as the vacant nursing rooms. The registration officer inquires about the availability of selected nursery room. If the selected treatment room is not available or is not suitable with the wish of the patients/their family, then the officer offers another nursery room. The registration officer makes an agreement about the nursery room with the patients/their family. The officer confirms the room to the selected treatment room.

The officer gives a brief explanation about the general agreement and inpatient agreement to the patients/their family, then both agreements is signed by both parties, which are the patients and the registration officer. The officer hands a waiting card to the patients/their family. The patients/their family is then welcomed to return to the outpatient unit/emergency unit (UGD).

The officer prepares a bundle of new medical record document and prints identity label as well as patients' identity bracelet. The contents of the document bundle are: patient's education and integrated family form, patient transfer in the hospital, initial inpatient medical assessment, inpatient medical resume, integrated patient progress record, nursery data assessment, nursery actions, nursery resume, plans and instructions for patient's return, initial pharmacy/medication reconciliation assessment, recipe assessment, nutrition screening, nutrition assessment, 
nutrition problems list, nutrition resume, medication administration list, vital signs graph, infusion and medical equipments record, laboratory check result, radiology check result, recipe copy, in-out summary, nosocomial infection.

60 identity labels are printed. Identity labels are then taped on patient's medical record document. The officer then completes the waiter's identity label and patient's identity bracelet. After all document are collected, they are put into maps according to color of each inpatient unit. Yellow is for Dahlia unit; blue is for Cempaka and Asoka unit; red is for Anyelir, Mawar, and Camelia unit; green is for Melati and UPKS; black is for UCU room.

The registration officer informs to the outpatient/emergency (UGD) unit as the initial patients' checkpoint that the patients' medical record document is ready. Outpatient/emergency (UGD) unit officer collects patients' medical record document in the registry. On the evening and night shift, the collection of patients' medical record document is done by the RM officer which they will have it delivered to the outpatient/emergency (UGD) unit.

During the time motion study measurement, several elements become a hindrance in the procurement of inpatients' medical record document, which are: frequency of TPPRI officers picking up both internal and external phonecalls as a media for visitors' inquiries. Visitors usually asks about doctor's schedules, inpatients' room location, patients' flow, and so on. Several of the things above often happen repeatedly when officers are currently processing inpatients' document. This condition will take even longer if done during poly specialist practice hours. Registration for JKN inpatients can take longer due to the higher number of documenting processes.

According to hospital minimum service standard, inpatients' medical record document procurement time is the time a patient is admitted to be hospitalized by the doctor until the inpatient medical record is available in the patient ward. The average time for registration of patients in TPPRI is $>15$ minutes. This average measurement has not put the time needed for doctors admitting for an inpatient and the time needed to transfer patients to inpatients room.

The result of FGD and time motion study are analyzed using fishbone diagram and 5 why-s. The fundamental understanding of fishbone diagram is that the basic problems are placed on the right side of the diagram or on the "head" of the fish skeleton. The impact of these problems are drawn on each fins and fish thorn/bone. ${ }^{6}$ Fishbone diagram and 5 why-s analysis result state that the root of the problems is :TPPRI officer overloads, there is no operational procedure standard (SPO) regarding the placement of identity labels, complicated medical record forms, the lack of understanding and counseling regarding the explanation of SPO and general consent, the needs to reorganizing inpatients registration SPO as well as land and human resource limitations.

\section{Fishbone Diagram Analysis}

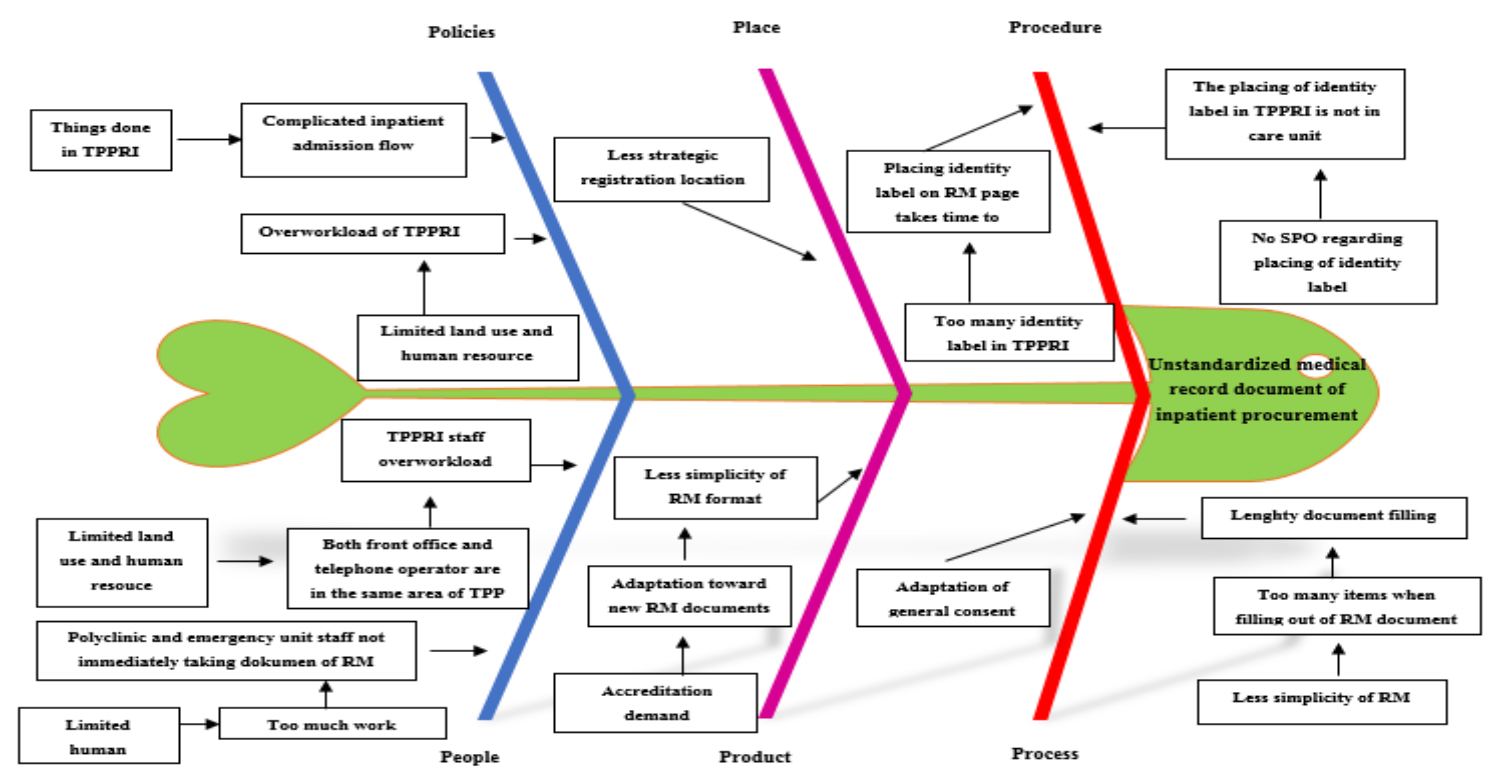

Figure 1. Fishbone Diagram 
There are several root problems that cause the procurement of inpatient medical record documents being substandard.
The priority of determining root problems is focused by performing USG on medical record unit.

Table 1. Root Problem Priority USG

\begin{tabular}{clcccc}
\hline NO & \multicolumn{1}{c}{ ROOT PROBLEMS } & U & S & G & TOTAL \\
\hline 1 & $\begin{array}{l}\text { Work overload, inpatient TPP officers doubling up work as front office receptionist } \\
\text { and phone operator. }\end{array}$ & 60 & 60 & 69 \\
2 & $\begin{array}{l}\text { Absence of SPO regarding identity label placing, there is only SPO regarding } \\
\text { identity label printing. }\end{array}$ & 39 & 34 & 25 & 98 \\
3 & Complicated medical record forms. & 49 & 47 & 43 & $\mathbf{1 3 9}$ \\
4 & Lack of understanding and counseling regarding explanation and general consent & 18 & 16 & 13 & $\mathbf{4 7}$ \\
& SPO & 55 & 54 & 49 & $\mathbf{1 5 8}$ \\
5 & The need to reorganize inpatient registration SPO & 55
\end{tabular}

The result of root problem USG labeled "work overload" has a total score of 179. TPPRI officer overload shows that apart from being inpatient registration officer, they are also front office receptionist and phone operator.

A company which needs a special attention regarding Human Resource work overload is Hospital. One of the vital organizational aspects of the hospital is human resource. ${ }^{7}$ Human Resource in hospital accounts for diverse staff, one of whom is medical record staff. TPPRI staff is included in medical record staff. Indonesian Republic Law no 36 in the year 2004 state that medical record staff is part of medical technician personnel. The duty of medical record staff is to process the patient's data into patient's health information, which is to manage the patient's data into useful information for the sake of decision making. ${ }^{8}$

In today's competitive era, an organization or a company constantly keeps finding ways to enhance the capacity of its human resources. This will lead to a new challenge in which how an organization can retain its human resources' skills. ${ }^{9}$ Skill of human resources is strongly demanded to be good. However, it is a fact that there are some phenomenon encountered by an organization which is stress-related problems faced by human resources. Work stress may appear due to excessive work load. This could bring some serious impacts to them and the hospital. ${ }^{10}$ This will result in work abandon by the staff. ${ }^{11}$ Due to negative effects caused by excessive work load, it needs work load calculation that a company/ an organization should conduct in evaluating its effectiveness, efficiency and human resources' work achievement. Regulation of

Ministry of Home Affairs Number 12 of 2008 regarding the guidelines for workload analysis within the Ministry of Home affairs sated that "The analysis of workload is a management technique performed systematically to gain the information regarding its effectiveness and efficiency of organizational work based on its work volume so as to gain the information regarding the number of employees, its working effectiveness and efficiency as well as unit in an organization". ${ }^{12}$ Hart in Murni (2012) claimed that workload appears from the interaction among work demands, work environment as work place, skills, attitudes and perception of the workers. ${ }^{13}$ Every work is a burden for its doer in the form of physical or mental activity. High workload, which is not suited with staff competence, will result in fatigue. Overworkload and lack of awareness from the organization could burden them. ${ }^{14}$ They will also haste their service because of the overworkload. ${ }^{15}$ This becomes a factor which makes them hasty.

The root problem in terms of document procurement of less standardized medical record is workload of TPPRI staff. This over workload results in work stress. This root problem needs to get its solution and one of the ways is to add the number of staff / human resource and / the equal distribution of work to related units. Some related units are emergency department, outpatient clinic and inpatient clinic. 
Table 2. Summary of Alternative Solution of Mc Namara

\begin{tabular}{ccccc}
\hline No & Alternative Solution & Effectiveness & $\begin{array}{c}\text { Efficiency } \\
\text { (Cost) }\end{array}$ & $\begin{array}{c}\text { Assessibility } \\
\text { Notal } \\
\text { telephone operator }\end{array}$ \\
\hline $\mathbf{2}$ & Distribution of daily to related units & 4 & 2 & 2 \\
\hline
\end{tabular}

\section{Barber Johnson Graph}

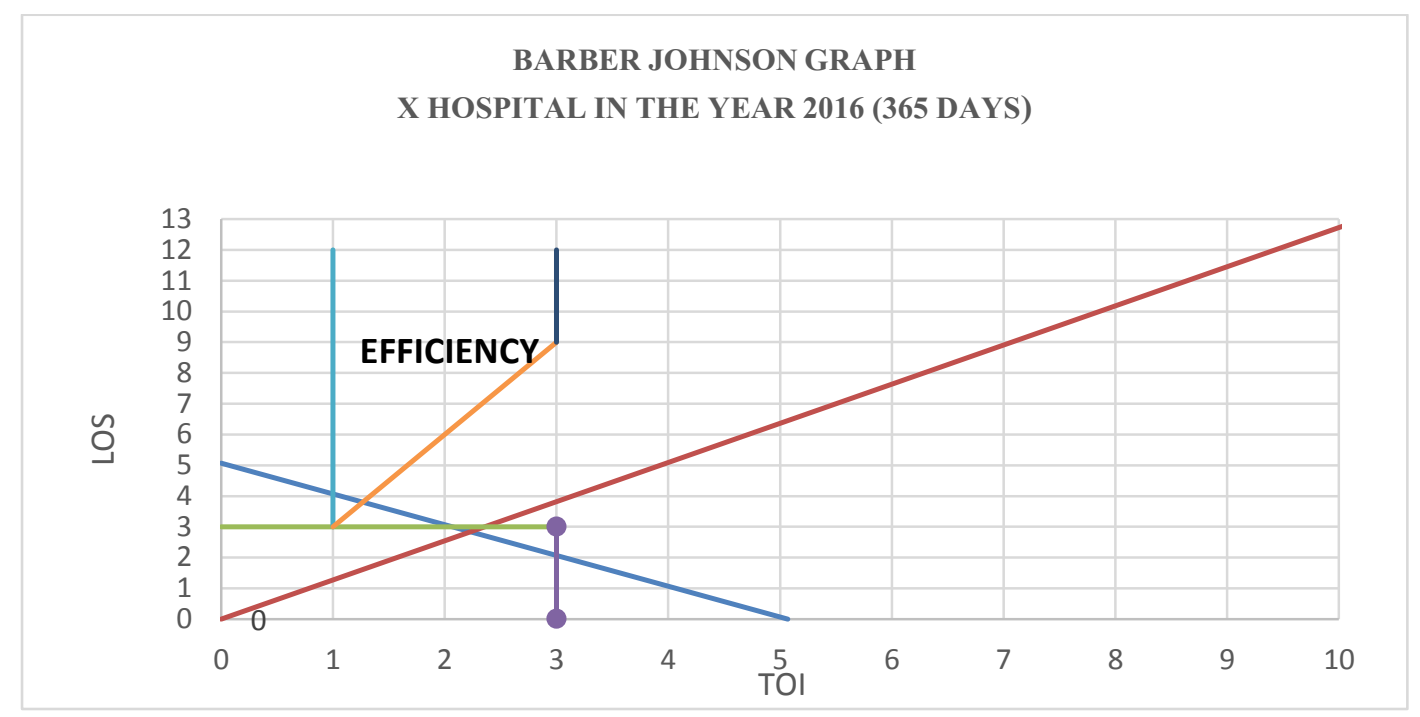

NOTE:

Figure 2. Graph of Barber Johnson

Priority of alternative solution is chosen through $\mathrm{Mc}$ Namara summary and graph analysis of Barber Johnson. Finding from tapisan Mc Namara indicates that daily workload distribution to related units is the solution. Barber Johnson graph is used to analyze workload in inpatient unit by analyzing 4 indicators of its efficiency level of $\mathrm{X}$ Hospital in the year 2016. BOR value indicates a rough workload performed by hospital medical staff. The higher value of BOR means the higher use of hospital beds to treat the patients. Sudra in Peni (2014) claimed that the more patients served mean busier and heavier workload medical staff has in inpatient units. ${ }^{16}$ In 2016 BOR accounted for $56 \%$, still under the level of efficiency of administering hospital, which means work load in inpatient unit is not too high. Distribution of workload to increase the quality regarding inpatient medical record procurement is possibly done in inpatient unit.

The solution of that root problem is by distributing daily workload of TPPRI staff to the related units, such as emergency unit, inpatient and outpatient units. Distribution of daily workload is as follows: The writing of the document and identity label placing available in TPPRI comprises only patient identity form, general consent and patient educational background and his integrated family. The other form is done in inpatient unit. A set of medical record documents for hospitalized patients have been well prepared in delivery unit, which is outpatient and emergency unit. It contains pages of: transfer of patients in 
hospital, inpatient initial medical assessment, inpatient medical resume, integrated patient medical progress note, assessment of nursing data, nursing plans, nursing resume, plan and guidance regarding patient hospital discharge, early pharmaceutical assessment/medical reconciliation, medical prescription analysis, nutritional screening, nutritional assessment, nutritional problem list, , nutritional resume, drug administration list, vital sign graph, infusion administration, and medical device note, laboratory examination finding, radiological examination result, copies of prescription, summary of hospital admission and discharge, nosocomial infection. The addition of equipment to print identity label in inpatient and emergency units.

To allow the distribution of daily work load run well, it needs Redesign of inpatient registration, redesign of SPO, the additional number of helpers in medical record installation to distribute medical record documents to the related

units.

\section{Flow of Inpatients}

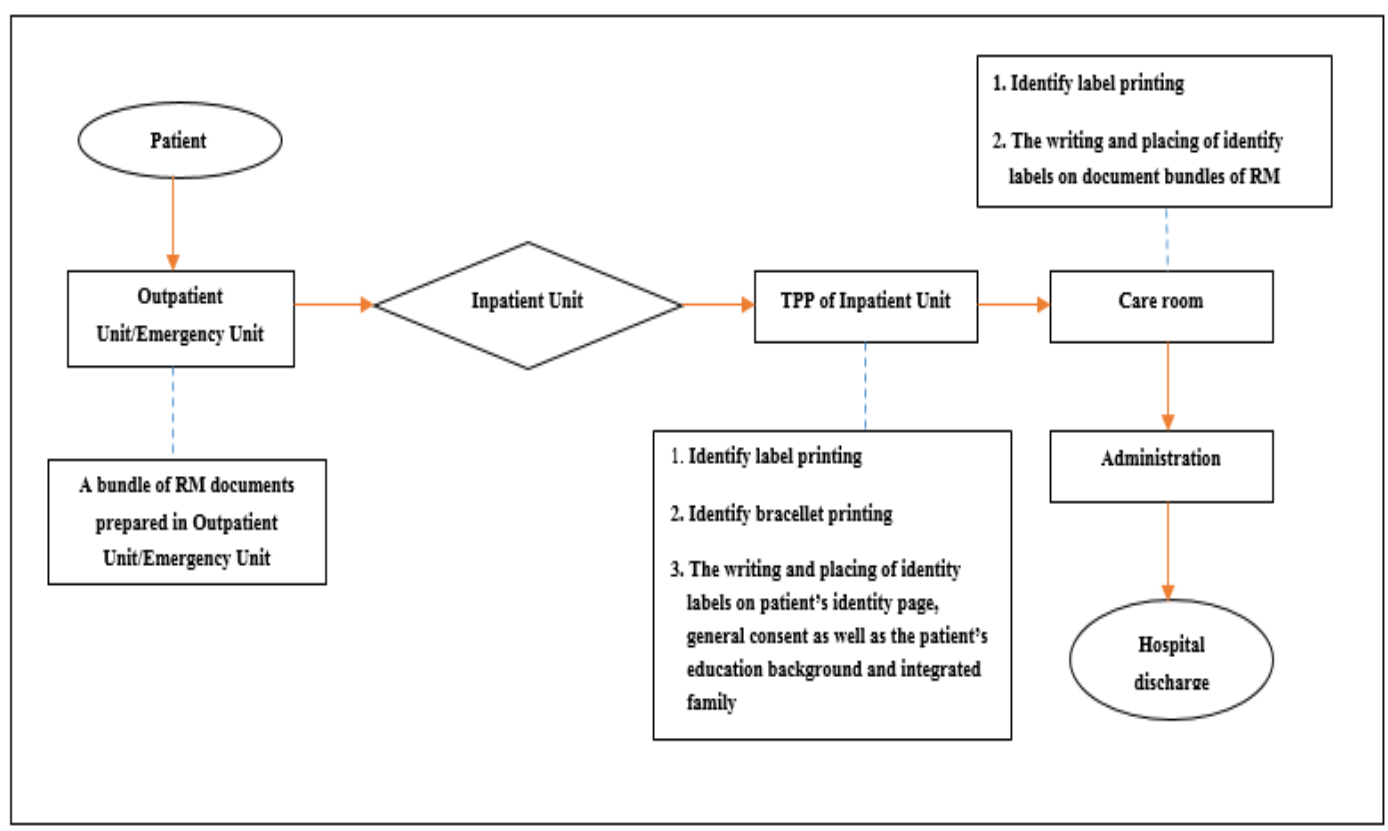

Source: Primary data and secondary data X Hospital

\section{CONCLUSION}

Overworkload of TPPRI staff can result in unmet / unstandardized inpatient medical record procurement. Their Overwork load comprise several responsibilities such as being TPPRI staff as well as being a front officer and telephone operator. The most probable applied solution is by distributing part of the staff workload to inpatient unit, emergency unit and outpatient unit.

If there is more land availability and human resource, separation of responsibility should exist between front officer and telephone operator. The collection of documents of inpatient medical record should have been started from the printing unit with specific designs that enable the staff to make it.

\section{REFERENCE}

1. Sukiatun S. Analysis Claim BPJS Review from Completeness of Medical Record Documents and Accuracy Diagnosis Codes in RSUD. dr. Iskak Tulungagung. Journal for Quality in Public Health. 2017; 1(1):1-12..

2. Mukti WY, Hamzah A, Nyorong M. Pengaruh Mutu Layanan Kesehatan Terhadap Kepuasan Pasien Rawat Inap di Rumah Sakit Woodward Kota Palu. Jurnal Akk. 2013; 2(3):35-41.

3. Sudrajat I, Sugiarti I. Hubungan Kecepatan Penyediaan Dokumen Rekam Medis Rawat Jalan 
Dengan Tingkat Kepuasan Pasien. Jurnal Manajemen Informasi Kesehatan Indonesia. 2015; 3(1).

4. Andria FD, Sugiarti I. Tinjauan Penyediaan Dokumen Rekam Medis di RSUD Dr. Soekardjo Kota Tasikmalaya. Jurnal Manajemen Informasi Kesehatan Indonesia. 2015; 3(2).

5. Romadhoni RD, Pudjirahardjo WJ. Beban Kerja Obyektif Tenaga Perawat Di Pelayanan Rawat Inap Rumah Sakit Objective Workload Of Nurses In The Inpatient Services At The Hospital. Jurnal Administrasi Kesehatan Indonesia. Januari-Juni 2016; 4 Nomor 1

6. Scavarda AJ, Bouzdin-Chameeva T, Goldstein S, Hays J, Hill A A Review Of The Causal Mapping Practice And Research Literature. Second world conference on POM and 15th annual POM conference; 2004.

7. Indrawati $\mathrm{AD}$. Pengaruh kepuasan kerja terhadap kinerja karyawan dan kepuasan pelanggan pada rumah sakit swasta di kota denpasar. Matrik: Jurnal Manajemen, Strategi Bisnis dan Kewirausahaan. 2013; 7(2).

8. Kristijono A. Analisis Kebutuhan Petugas Pendaftaran Pasien Berdasarkan Metode Workload Indicator Staff Need (WISN) Di Rumah Sakit Islam Sultan Agung Semarang. Jurnal Manajemen Informasi Kesehatan Indonesia. 2017; 5(1).

9. Hartomo A, Noor NB. Gambaran Beban Kerja Unit Administrasi Di Rumah Sakit Unhas. Fakultas Kesehatan Masyarakat, Universitas Hasanuddin, Makassar. 2013.
10. Vargas C, Cañadas GA, Aguayo R, Fernández R, Emilia I. Which occupational risk factors are associated with burnout in nursing? A meta-analytic study. International Journal of Clinical and Health Psychology. 2014; 14(1):28-38.

11. Qureshi MI, Iftikhar M, Abbas SG, Hassan U, Khan K, Zaman K. Relationship Between Job Stress, Workload, Environment And Employees Turnover Intentions: What We Know, What Should We Know. World Applied Sciences Journal. 2013; 23(6):764770.

12. Daraba D, Saggaf MS. Analisis Kebutuhan Pegawai Di Sekretariat Daerah Kabupaten Maros. Jurnal Ad'ministrare. 2015; 2(1):16-26.

13. Kasmarani MK. Pengaruh beban kerja fisik dan mental terhadap stres kerja pada perawat di Instalasi Gawat Darurat (IGD) RSUD Cianjur. Jurnal kesehatan masyarakat. 2012; 1(2):676-776.

14. Viviers S, Lachance L, Maranda M-F, Ménard C. Burnout, psychological distress, and overwork: the case of Quebec's ophthalmologists. Canadian Journal of Ophthalmology. 2008; 43(5):535-546.

15. Kc DS, Terwiesch C. Impact of workload on service time and patient safety: An econometric analysis of hospital operations. Management Science. 2009; 55(9):1486-1498.

16. Indriani $P$, Sugiarti I. Gambaran Effisiensi Penggunaan Tempat Tidur Ruang Perawatan Kelas III di Rumah Sakit Umum Daerah Tasikmalaya Tahun 2011 Dan 2012. Jurnal Manajemen Informasi Kesehatan Indonesia. 2014; 2(1). 